where different tenures, attitudes, and water supplies made its intensive modern input approach nonviable.

In the course of her work, Kusum spent shorter or longer periods of time at Harvard, Michigan State, the East-West Center, Chicago, Guelph, Cornell, Missouri, Wisconsin, and Maryland, before settling for the last eight years at Kansas State University. There she struggled to cap her career by contriving an epic recounting of the agricultural history of the United States, with the intent of debunking the heady myths woven into standard renditions. Only a portion of this manuscript was completed when she died on December 13, 1993, at the age of 74. The lessons of Kusum Nair's lifework will advance rather than recede in significance as the onmarching decades confront large portions of the human species with challenges to survival. She would have wanted nothing more from her life. To those who knew her, Kusum will always be a radiant blossom in the dust.

JOHN ADAMS

Nortbeastern University

\title{
ATTIPAT KRISHNASWAMI RAMANUJAN
}

$(1929-1993)$

A. K. Ramanujan, one of the outstanding interpreters of South Indian civilization in this generation and a major poet in Kannada and English, died in Chicago on July 13, 1993. A masterful translator, linguist, folklorist, teacher, and scholar, Raman - as we knew him-was above all a deeply loved and loving human being, with an unparalleled talent for friendship. Entire disciplines, enlivened by his insights, are bereaved by his passing; the loss to South Asian studies as a whole is beyond measure or imagining.

Raman was born and raised in a Tamil Srivaisnava family settled in Mysore. His mother was devoutly orthodox. His father, a famous mathematician, was at home in several worlds: Western mathematicians and scientists passing through India, as well as Sanskrit pandits and traditional astrologers, frequented the Mysore house, where Raman's father had his study upstairs; but Raman himself preferred the kitchen downstairs, an inner, largely female domain that was alive with stories told in his Tamil mother-tongue. Kannada outside in the streets, Tamil downstairs, English and Sanskrit upstairs - this linguistic distribution in space, so rich in meaning, in many ways molded Raman's inner world. All his life he was fascinated by the transitions and exchanges between two primary modes so concretely embodied in his childhood experience-akam and puram, the inner and outer spaces, mothertongues and father-tongues, the folktales told in the former and the myths composed in the latter, with their different textures and structures of authority. This categorical division would become a major theme in the cognitive maps he offered of South Indian culture. 
Growing up in a Kannada cultural environment, he learned to read Tamil from the cartoons in journals that arrived regularly from Madras. His formal training, however, was initially in English language and literature (he received his B.A. and his M.A. in this subject from the University of Mysore), and throughout his life he retained a vibrant expertise in Shakespeare and Milton. His first academic appointments were as lecturer in English at S.N. College, Quilon (Kerala), Thiagarajar College in Madurai (Tamil Nadu), Lingaraja College in Belgaum (Karnataka), and M.S. University in Baroda (Gujarat). He was also drawn to theoretical linguistics, receiving a graduate diploma in this field from Deccan University in Poona in 1958 and a Ph.D. from Indiana University in 1963.

In 1962 he was appointed assistant professor at the University of Chicago, the beginning of a lifelong association with this university, where he would help shape the course of South Asian studies in a period of remarkable creativity and growth. He was William H. Colvin Professor in the Department of Sourh Asian Languages and Civilizations, the Department of Linguistics, and the Committee on Social Thought. It was in the Regenstein Library at Chicago that, in 1962, he stumbled upon U. V. Caminataiyar's classic editions of the ancient Tamil Cankam poems, with a modern commentary that Raman found, to his surprise, to be remarkably transparent. In this way the archaic poems revealed themselves to him, choosing him, unerringly, as their translator; an entire generation knew the wonders of this great literature through his work, first published as The Interior Landscape (1967) and later as the much-expanded Poems of Love and War (1985). A similar process of autodidactic exploration, energized by his poetic sensibilities, led to his translations from the Kannada Virasaiva vacanas (Speaking of Siva, 1973) and from his own inheritance, the Tamil Alvars (Hymns for the Drowning, 1981). So stunning and fresh are these poetic translations that readers would occasionally react with disbelief, even wondering if Raman had not, perhaps, "invented" the originals himself. In fact, his method of translation was scrupulously keyed to the literal wording of the text; he would allow himself no short-cuts and no lyrical enhancements, though he was at times prepared to take the kind of risks, the sudden leaps of correspondence, that only genius makes possible. His translations-minimalist and musical-inevitably illumine the original with flashes of insight, the gift of a poet translating from his native language into a second language that has become paradoxically more than native, a consciously chosen second home.

He had the poet's perfect pitch, never using language carelessly or imprecisely. Perfectly trilingual-in Tamil, Kannada, and English-he deliberately renounced the temptation of learning other languages, as if unwilling to endanger the delicate linguistic balance within him. Despite himself, however, he was increasingly drawn to Sanskrit-another paternal legacy assimilated during his Mysore childhoodand, in recent years, to Telugu. His last book, produced together with V. Narayana Rao and myself, was a selection of Telugu padams, devotional love-poetry sung by courtesans in Nayaka-period Tanjavur (When God is a Customer, 1994; sadly, he did not live to see this book's appearance). Here, too, the language captivated him, moving him to amazing feats of listening and transmutation. The Ksetrayya padams are intensely erotic, reflecting a courtesan's ambience and taste; night after night the three of us would work on them for hours in Raman's Jerusalem apartment. One day he complained to me that he was unable to sleep after these late-night sessions, and I, perhaps too quickly, said I understood. "No, not that," he said, "the words, the words!" 
Raman's own Kannada poems wrought major changes in the world of modern Kannada poetry, and he was unquestionably one of the finest English poets of his generation in India. No one who heard him recite his work, or tell a folktale, or teach a class, could ever forget the vision of this slight, soft-spoken man electrifying an audience with his voice-unusually resonant and alive with a gentle, selfdeprecating, always penetrating wit. His attentiveness-to people, to texts, to any form of language-knew no limit; he transformed the lives of nearly everyone he touched, either directly or through his printed works. When in $1971 \mathrm{I}$ first heard the word "Tamil" while I was searching unsteadily for a graduate field of studysomething powerful enough to sustain a lifelong fascination-I went to the library of the Hebrew University to see what literature existed in this exotic tongue. There was one book: Raman's Interior Landscape, exquisite translations of Cankam poems, with a lucid and understated Afterword by the translator. That was enough.

He had the good fortune to be recognized and rewarded in his lifetime: the Government of India awarded him the title "Padma Sri" in 1976, and he received a MacArthur Prize Fellowship in 1983. Students flocked to his feet, and many universities competed for his presence; he taught at Harvard, the University of Wisconsin, the University of Michigan, the University of California at Berkeley, and Carleton College, and lectured at institutions of learning throughout the world. His bold essays of interpretation and integration- "Is there an Indian Way of Thinking?" "Where Mirrors Are Windows," "Telling Tales," to name but threehave become classics. The impact of his work extended far beyond South Asian studies proper: he unveiled the riches of hitherto unfamiliar literatures for the benefit of the English-speaking world, and his work in collecting and analyzing Indian folktales reached out to wider audiences of folklorists and literary scholars (his 1992 collection, Folktales From India, bears the hallmarks of his lively taste and careful choosing; a large volume of Kannada tales, painstakingly collected and translated, still awaits publication). In a fundamental sense, however, the many honors hardly touched him; a truly modest man, he often voiced self-doubt, disclaimed scholarly achievements.

Raman disliked adjectives. He taught his students to avoid them. He would surely have disapproved of many that spring to mind in this sad context, as one gropes for ways to hold him here, not surrendering to the loss. Among his many unfinished projects was a deeper exploration of Kampan's medieval Tamil Ramayana, and I can do no better here than to quote from Kampan's lament for Raman's namesake, the epic hero Laksmana/Ramanuja, prematurely slain:

Terrible things do happen-

demons may kidnap good women, evil may overtake the gods,

and still the worlds just go on turning, turning without end-

as if there were nothing

we could do...

We may live on,

perhaps for long,

but the heart that was whole before

is split in two.

David Shulman

Hebrew University 